\title{
SARCOIDOSIS AS A CAUSE OF TRANSVERSE MYELITIS: CASE REPORT
}

\author{
By Jordana Baum, M.D., ${ }^{1}$ Marcel Solomon, M.D., ${ }^{1}$ and Augusta Alba, M.D. ${ }^{2}$ \\ ${ }^{1}$ New fersey Rehabilitation Hospital, East Orange, $\mathrm{NF}$ 07018, and ${ }^{2}$ New York University \\ Medical Center, Goldwater Memorial Hospital, NYC 10044
}

THIs is an unusual case of a patient with paraplegia who had severe neurological and pulmonary involvement and was eventually diagnosed as having sarcoid myelopathy on the basis of the following findings:

I. Recurrent neurological problems, including three episodes of acute meningo or encephalo myelitis, immediately preceded by left parotid gland enlargement.

2. Parallel with this (but not coinciding with it), recurrent pulmonary problems, including bilateral hilar adenopathy, unexplained cavitation, and recurrent infiltrates.

3. Prolonged periods of unexplained fever.

4. A dramatic response of all of the above, at one time or another, to steroid therapy after antibiotics had failed.

5. Immunological responses; $a$. a possible positive Kveim test, $b$. anergy to tuberculin and other skin tests, $c$. hypersensitivity reaction to antibiotics.

6. The exclusion of other possible causes (tuberculosis, fungal infection, viral infection, collagen diseases).

\section{Case Report}

This is a case history of a 23-year-old girl, spanning a period of eight years and involving several hospitalisations. The first admission occurred in 1972 for acute meningomyelitis, which rendered the patient paraplegic at T-I2 sensory level. The neurological symptoms and signs were preceded by left parotid gland swelling. After two months the patient developed bilateral hilar adenopathy, recurrent pulmonary infiltrates, and at one point, a cavity in the right upper lobe. The pulmonary problems resolved practically without treatment (without antibiotics).

A year after the first neurological episode another bout of acute meningo-encephalitis occurred which rendered the patient hemiplegic (left upper extremity and central facial nerve involvement). Without treatment the hemiplegia resolved in two months. During this time the patient had intermittent low grade pyrexia of undetermined aetiology.

A third neurological relapse occurred three years later. There was a repetition of an almost explosive onset of aseptic meningitis, immediately followed by tetraplegia. Just prior to this neurological episode the patient had low grade intermittent fever, and swelling of the left parotid gland. At that point, our clinical impression was that she had a systemic disease, possibly sarcoidosis. To confirm our diagnosis of Sarcoid Myelopathy, a Kveim test was performed. Ten days later, the patient developed a nodule at the injection site. This was exactly the time when the patient had her third neurological relapse with quadriplegia. The condition was treated with broad spectrum antibiotics, to which the patient did not respond. Only after steroid treatment did the fever subside and paralysis of both upper extremities and trunk regress completely. Naturally, the nodule which was observed ten days after the Kveim test disappeared completely. Therefore, the biopsy of the nodule was not carried out. 
Cerebrospinal fluid study revealed pleocytosis, increase in protein content and decrease in glucose level. Multiple cultures have always been sterile. The liver function profile was within normal range, except for the gammaglobulin fraction in plasma which was elevated most of the time. myelitis.

After the third neurological relapse, there were no further episodes of meningo-

\section{Discussion}

Sarcoidosis of the nervous system has been more frequently diagnosed in recent times. Incidence ranges between 3.5 to 7 per cent. Spinal cord parenchymal involvement in sarcoidosis represents one of the least common forms of neurosarcoidosis. The review of the literature shows only 17 histologically verified cases of spinal cord sarcoidosis. A few more cases have been reported without histological proof, based on clinical and radiological grounds (Wierderhold, I956; Matthews, I965).

In our case the diagnosis is based on clinical grounds with evidence of neurological dysfunction, systemic manifestations of the disease, ample radiological evidence of chest pathology and an equivocally positive Kveim test. We would like to point out that each acute neurological episode in our patient started in an explosive manner with signs and symptoms of acute meningitis and transverse myelitis and/or acute hemiplegia. The literature revealed no description of such an explosive onset of exacerbation of neurosarcoidosis.

Neurosarcoidosis should be considered in the differential diagnosis of transverse myelitis and aseptic meningitis, especially in view of the potentially favourable response to steroid therapy.

\section{RÉSUMÉ}

La sarcoidose affécte le sustem nerveux central dans 3.5\%-7\% des cas. L'atteinte de la moëlle épinière est encore plus rare. En l'absence de la confirmation anatomique, le diagnostique repose sur des moyens cliniques et de laboratoire. L'épreuve Kveim positive est trés utile pour confirmer le diagnostique. La thérapie avec corticostéroides appliquée en due temps peut être utile pour prévenir, améliorer ou controller les déficits néurologiques produits par la sarcoidose de la moëlle épiniere. Nous soulignons l'importance de l'hospitalization et du traitment si tôt que possible, non seulement pour la rehabilitation du sujét, mais aussi pour prévenir les complications urologique et dermatologique.

\section{ZUSAMENFASSUNG}

Sarcoidose des Nervensystems ist heute weitgehend anerkant. Vorfall der Neurosarkoidose liegt zwischen 3,5\% bis $7 \%$. Rueckenmarkparenchymschaeden durch Neurosarkoidose kommen euserst selten vor. Bis jetzt wurde ueber nur 17 Faelle berichtet. Oft kann man eine Biopsie zur Bestaetigung der Diagnose nicht ausfueren, jedoch kann die Diagnose durch klinische Beobachtung und Laborunersuchungen festgestellt werden. Der Kveim Test kann hier nuetzlich sein. Fruehzeitige Erkennung der Rueckenmarksarcoidose ist wichtig da Behandlung durch Corticosterpiden eine Regression der neurologischen Schaeden erwirken kann. Wir betonen nachdruecklich das vorzeitige Behandlung im Krankenhaus wie auch Rehabilitation der Patienten mit Neurosarkoidose, um Beschaedigungen der Nieren, Harnblase und Haut, vorzubeugen, ueberaus wichtig ist.

\section{REFERENCES}

BANERJEE, T. \& Hunt, W. E. (1972). Spinal cord sarcoidosis-Case Report, F. Neurosurg, 36 (4), 490-493.

BernsteIn, J. \& RIVAL, J. (1978). Sarcoidosis of the spinal cord as the presenting manifestation of the disease. Southern Medical F, 71, I 57 I-I 573. 
Campbell, J. N., Black, P. \& Ostrow, P. T. (I977). Sarcoid of the cauda equina-Case Report. F. Neurosurg, 47, I09-I I2.

Ceuppens, J. \& STEVENS, E. (I978). Immunological aspects of sarcoidosis-Review. Acta Clin Belg, 33 (2): 78-97.

Colover, J. (1948). Sarcoidosis with involvement of the nervous system. Brain, 71, $45 \mathrm{I}-473$.

Day, A. L. \& SyPert, G. W. (1977). Spinal cord sarcoidosis. Ann. Neurol., I (I), 79-85.

Delaney, P. (1977). Neurologic manifestations in sarcoidosis and intern. med., 87, 336-346.

Douglas, A. (1972). The Kveim test and its practical significance, Scand. F. Resp. Dis. Suppl., 80, 6I-70.

FitzPATRICK, D. P. \& Ewart, G. E. (I957). Central nervous system sarcoidosis successfully treated with prednisone. Arch. Inter. Med., 100, I39-I 42.

GoEBEL, G. (I975). Myelitis transversa als fruehmanifestation einer sarkoidose, Nervenarzt, 46, 688-689.

JAMES, D. G. (1975). Kveim revisited, reassessed. New England f. Med. (292), 16, 859-860.

JEFFERSON, M. (I957). Sarcoidosis of the nervous system. Brain, 80, 540-555.

KIRKS, D. R. \& NEWTON, T. H. (I972). Sarcoidosis-a rare cause of spinal cord videming. Radiology, 102, 643.

LebAco, E. G. (1977). Reassessment of the Kveim test in the diagnosis of sarcoidosis. Acta. Clin. Belg., 32 (4), 22 I-222.

Matthews, W. B. (1965). Sarcoidosis of the nervous system. F. Neurol. Neurosurg Psychiat., 28, 23-28.

McGovern, J. P. \& Merritt, D. H. (1956). Sarcoidosis in childhood. F. Advanc. Pediat., $8,97-135$.

Mikhail, J. R. \& Mitchell, D. N. (1970). The Kveim test in sarcoidosis, Postgrad Med.F., 46, 484-485.

Mitchell, D. N., Rees, R. J. W. \& Bradstreet, C. M. P. (I97I). Is the Kveim test safe, Lancet, I (705), 907.

Nathan, M. P. R., Chase, P. H., Elquezabel, A. \& Weinstein, M. (1976). Spinal cord sarcoidosis, NY State F. Med., 76, 748-752.

Nelson, C. T. (1957). The Kveim reaction in sarcoidosis. 7. Chron. Dis., 6, I 58-175.

Odero, D., Matthay, R. A. \& Gee, B. L. (1976). Hemoptysis with cavitary lung lesion. F $A M A, 236$ (25), 2889-2890.

SCHIFFNER, R. O. \& SHARMA, OM. P. (1977). Acute pulmonary cavitation in sarcoidosis, Western F. Med., I27 (4), 346-349.

SEMINS, H., NugENT, G. R. \& GHOU, S. M. (I972). Intramedullary spinal cord sarcoidosis, Neurosurgery, 37, 233-235.

SNYDER, R., Towfighi, J., \& Gonatas, N. K. (I976). Sarcoidosis of the spinal cord, F. Neurosurg., 44, 740-743.

Tellis, M. C. J. \& Putnam, J. S. (1977). Cavitation in large multinodular pulmonary. Disease Chest, 7I (6), 792-793.

Wiederhold, W. C. \& SiEKERT, R. G. (1956). Neurological manifestations of sarcoidosis. Neurology, 15, I I47-I I54. 